\title{
The Impact of Ethical Practices on the Performance of Small and Medium Enterprises in South Africa
}

\author{
Obey Dzomonda, Olawale Fatoki \\ Department of Business Management, Turflop Campus, \\ University of Limpopo, Limpopo Province, South Africa \\ obeydzoms@gmail.com, olawale.fatoki@ul.ac.za
}

\begin{abstract}
SMEs have become beacons of hope towards improving economic growth and development of many countries globally. However, the literature documents a high discontinuance rate among small businesses. The purpose of this study is to investigate the impact of ethical practices on the performance of SMEs in South Africa. The study was based on a quantitative research design. The survey method was used as a data collection method. Using this method, self-administered questionnaires were used as the primary data collection tool. These questionnaires were hand delivered to the participants by the researcher. The random sampling method was used to obtain the participants. The population consisted of SME owner/managers in Polokwane municipality. 74 SME owner/managers participated in the survey. Data analysis included descriptive statistics, factor analysis, $\mathrm{T}$ tests and regression analysis. The Cronbach's alpha was used as a measure of reliability. The findings showed that SMEs display unethical behavior and a weak performance. It was discovered that SMEs does not have policies in place to guide their ethical behavior. The $\mathrm{T}$ test results showed significant differences between gender and education levels with ethical practices of SMEs. The regression results showed that there is a positive relationship between ethical practices and performance of SMEs. Recommendations were made for SMEs to treat ethical issues seriously lest they risk incurring costs associated with lawsuits and negative brand reputation.
\end{abstract}

Keywords: Behaviour, ethics, performance, SMEs, South Africa

\section{Introduction}

Small businesses are increasingly becoming important key players towards economic prosperity of nations across the globe (Peprah, Mensah \& Akosah, 2016). There is a growing trend worldwide towards considering SMEs as economic drivers and engines for economic growth and development (D'Imperio, 2012). However, it is difficult to understand the contribution of SMEs without understanding their definition. The African Development Bank (2007) points out that defining the term SME is the first step in conducting a policyrelevant analysis to solve problems related to the sector. According to Dada (2014), there is no universally acceptable definition of SMEs. However, in South Africa, the National Small Business Act of South Africa 1996 as amended in 2003 defines a small business as "a separate and distinct entity, including cooperative enterprises and non-governmental organizations managed by one owner or more, including its branches or subsidiaries if any is predominantly carried out in any sector or sub-sector of the economy mentioned in the schedule of size standards, and can be classified as an SME by satisfying the criteria mentioned in the schedule of size standards" (Government Gazette of the Republic of South Africa, 2003). This definition tallies with international standards as it employs both the qualitative and quantitative definitions. Ilegbinosa and Jumbo (2015) point out that globally, SMEs contribute immensely towards the gross domestic product (GDP). Firoozmand, Haxel, Jung and Suominen (2015) highlight that SMEs are the economic backbone in the U.S. SMEs play an important role in most developing countries by creating jobs for both the urban and the rural populace (Kongolo, 2010).

Ramukumba (2014) notes that SMEs in developing countries greatly assists in evenly distributing opportunities and wealth which result in poverty reduction. According to International Finance Corporation Report (2013), the largest share of employment in developing countries belongs to small and medium enterprises (SMEs). Regardless of the positive contributions made by SMEs to the economy of South Africa, the SMEs' business discontinuance rate is notoriously high in South Africa. This is attributed mainly to factors such as lack of finance, crime, lack of management experience, lack of functional skills, poor attitudes towards customers, ineffective leadership styles and conduct of unethical behavior among others. This study is driven by the desire to elaborate on the impact of ethics on the performance of SMEs. The study is of significance in 
the sense that it intends to generate empirical findings on the relationship between ethical practices and performance among SMEs from a South African perspective. Furthermore, the findings of the study will help improve the theoretical framework for business ethics. In light of the contribution of the SME sector in South Africa, it is of significance to investigate factors that can improve their performance. Hence, the findings of the study will be useful to SME owners and organizations that assist SMEs to better understand factors that can help to improve the performance of SMEs in South Africa.

The objectives of the study: The objectives of the study are:

- To explore the ethical practices of SMEs

- To examine the relationship between gender and ethical practices of SMEs

- To assess the effect of age on the ethical practices of SMEs

- To determine the relationship between ethical practice and performance of SMEs

\section{Hypotheses}

$\mathbf{H}_{\mathbf{0}}$ : There is no relationship between gender and ethical practices of SMEs

$\mathbf{H}_{\mathbf{1}}$ : There is a significant relationship between gender and ethical practices of SMEs

$\mathbf{H}_{\mathbf{0}}$ : There is no relationship between education and the ethical practices of SMEs

$\mathbf{H}_{2}$ : There is a significant relationship between education and the ethical practices of SMEs

$\mathbf{H}_{\mathbf{0}}$ : There is no relationship between ethical practices and performance of SMEs

$\mathbf{H}_{3}$ : There is a significant relationship between ethical practices and performance of SMEs

\section{Literature Review}

Smit, Cronje, Brevis and Vrba (2007) and Hellriegel, Jackson, Slocum, Staude, Amos, Klopper, Louw and Oosthuizen (2008) describe ethics as a set of values or guiding principles which aim to separate right and wrong behaviors. As such, an individual or an organization is obliged to act or behave in a manner deemed acceptable and rightful. This study is grounded on the stakeholder theory. The theoretical background of ethical practices and performance of SMEs augurs well with the stakeholder theory. The stakeholder theory by Freeman (1984) is a theory rooted in the organizational management philosophy on how different organizations should deal with ethical issues in a business context. Stakeholder theory begins with the assumption that values are necessarily and explicitly a part of doing business. The theory emphasizes that managers should be guided by a set of values, which in turn assist them in managing relationships with their different stakeholders. Stakeholders include shareholders, employees, suppliers (goods and funds) customers, and the communities in which the firm operates. The stakeholder theory clearly underlines the importance of running a business ethically (Freeman, Wicks \& Parmar, 2004). However, a few studies schemes, Key (1999) challenge the validity of the stakeholder theory arguing that it lacks a solid theoretical validation. Nevertheless, this theory forms an important aspect of this study as it provides a framework to formulate ethical principles for small businesses. In addition, Key, Bewley and Vault (2004) argue that the stakeholder theory still stands as an important theory to explain CSR in organizations.

Lather (2009) argues that businesses should aim at improving ethical practices related to customers and suppliers as they determine the sustainability of the business. On that note, it is crucial for SMEs to address issues relating to; corporate social responsibility, employees, customers and how they relate with their suppliers. However, Vivier (2013) report that most SMEs are solely run, which result in one managing the business without any formal written ethical policies. Consequently, SMEs lack formal structures and policies to deal with shareholders, suppliers, employees, the community and the ones relating to how they respond to customer complaints as compared to large businesses (Arruda, 2010; Spence \& Perrini, 2010). Arruda (2010) notes that SMEs compromise ethical principles whenever they perceive an economic gain. A study conducted by Vivier (2013) showed that a number of SME owners agreed that they act unethical to be profitable. In some cases, SMEs often tries to avoid involving themselves in corporate social responsibility activities, citing that it's only applicable to profitable large businesses (Spence \& Painter-Morland, 2010; Schlierer et al., 2012). Ethical challenges faced by new SMEs include not meeting commitment to suppliers, perception of dishonesty and lack of business experience, skills and competencies. A study by Viviers and Venter (2008) 
report that SMEs are involved in fraudulent activities. The authors of this study believe that unethical conduct exhibited by SMEs is among the top reasons why their loan applications are turned down by banks. Fatoki (2012) concurs and asserts that SMEs in South Africa exhibit high levels of unethical behavior which seriously compromise their sustainability.

Gender and ethical practices of SMEs: Gender is a crucial element to consider in the bid to resolve unethical behaviour displayed by some small businesses. On that note, it is important to investigate if there are gender differences in the ethical stance or behaviour exhibited by SME owners. Dawson (2013) argues that gender difference in ethical behavior is a reality than a myth. On that account Dawson (2013) notes that gender differences in ethical behavior exhibited by men and women are attributed to gender socialization. This explains why women tend to be more ethical than men as indicated by Hazlina and Seet (2010). Similarly, Castejón and López (2016) note that women are philanthropic which makes them ethical as compared to men who are driven by the desire to surely make economic gains. This makes men to embark on unethical practices more than women. Chinchilla and Jiménez (2013) remark that women tend to consider the longterm consequences that may arise due to unethical decisions more than their male counterparts. The literature about the relationship between gender and ethical practices of SMEs is inconclusive. Dutta and Banerjee (2011) found out that the women displayed unethical behavior compared to men in their study. However, the authors of this study believe that by nature women are risk averse hence, they are less likely to be involved in fraudulent activities and corruption as compared to men. Therefore, it can be hypothesized that there are gender differences on the ethical practices of SMEs.

Level of education and ethical practices of SMEs: It is important to critically investigate the determinants of ethical behavior among SMEs. This is crucial as it informs policy making. As such, the authors of this study believe that education is a good predictor of ethical behavior among SMEs. A study by Herrera et al. (2014) indicates that people with university qualifications tend to take ethical issues more seriously than their counterparts with non-university qualifications. Similarly, Dutta and Banerjee (2011) found out that people who have acquired tertiary qualifications are sensitive to ethical issues than their uncertificated counterparts. They further reasoned that educated owners understand the long-term consequences of unethical behavior hence, their desire to act within expected codes of conduct. University education is instrumental in shaping ethical behavior among individuals since ethics and corporate social responsibility are engraved in the modules taught in institutions of higher learning (Pérez, 2010; Larrán Jorge, AndradesPẽna, \& Muriel de Los Reyes, 2014). It can be hypothesized that, there is a significant difference on the ethical practices of SMEs based on the level of education.

Ethical practices and performance of SMEs: According to Manaf and Latif (2014), performance is the ability of an organization to fulfil the demands of the investors by assessing the company's achievements. In this study performance is measured in terms of market share growth, sales, profitability, return on assets, employment growth, customer satisfaction and employee satisfaction. Donker, Poff and Zahir (2008) found that ethics positively influence workers to take responsibility of their work which results in improved firm performance. Hilman and Gorondutse (2013) found perceived ethics to be positively associated with SMEs' performances. According to Ahmad et al. (2012), it is also important to take into consideration the issue of corporate social responsibility (CSR) when discussing about ethics among small businesses. This is because CSR is often neglected by SMEs regardless of the positive benefits it can bring to their organizations. Kamyabi, Barzegar \& Kohestani (2013) and Brammer (2007) found a positive relationship between CSR and financial performance. Dutta and Banerjee (2011) find that adhering to ethical standards can improve the performance of small businesses beyond national borders. Therefore, it can be hypothesized that there is a significant relationship between ethical practices and performance of SMEs.

\section{Methodology}

The study focused on a population of 250 SMEs in Polokwane municipality. Polokwane was chosen because it is an area with a high concentration of SMEs in Limpopo province. This creates a high probability to get accurate representation and a true reflection of SMEs in South Africa. The quantitative research method was adopted for this study and 156 SMEs were surveyed. The sample size was deemed adequate enough for the 
study after following recommendations by Sekaran and Bougie (2010) that a sample should be sufficient enough in order to draw accurate generalizations. The sample size was determined by Raosoft sample size calculator which takes into consideration: the margin of error, confidence level and population size. The random sampling technique was used in the study. Data was collected through the use of self-administered questionnaires in a survey. The questionnaire for the study consisted of three sections; (1) biographical questions (2) ethical practice questions and (3) questions related to SMEs performance. The questions in the questionnaire were all closed ended questions. The research also made use of the 5 point Likert scale questions for both ethical practice and performance. The Lickert scale questions ranged from strongly disagree to strongly agree for ethical practice questions and for performance it ranged from excellent to no idea. Data was analyzed using descriptive statistics, factor analysis, T test and regression analysis. Descriptive statistics were run to summarize data on the ethical practices and performance of SMEs. Factor analysis was run to check if the variables of the different ethical practices confirm the underlying constructs as indicated in the existing literature while the $\mathrm{T}$ tests were used to compare mean differences between gender and education with the ethical practices of SMEs. According to Kim (2015), "t- tests are usually used in cases where the experimental subjects are divided into two independent groups, with one group treated with A and the other group treated with B." Regression analysis was conducted to test the hypothesized relationships between ethical practices and performance of SMEs. In this study, ethical practices were the independent variable while performance was the dependent variable of the study. The Cronbach's alpha was used to measure reliability.

\section{Results and Discussion}

Response rate: One hundred and fifty-six questionnaires were hand delivered to SME owners in Polokwane Municipality. Seventy-four questionnaires were returned and filled properly, making a response rate of 47 percent.

Biographical information: To understand business ethics and dynamics fully among SMEs, it was important to also capture the SME owners' and firm characteristics. The results indicated that a significant number of the participants were males (65\%) compared to only (35\%) females. The dominant age of the respondents was 31-40 years. The findings are in agreement with similar studies (Tsele, 2015). Considering the level of education, the findings indicate that a significant number of the respondents (61\%) have matric and below qualifications. Studies such as Agbenyegah (2013) share similar findings. It was further discovered that most small businesses in the study area (35\%) are solely run and operated, dominating in the retail sector. Considering employment creation, most respondents indicated that they employ under 5 employees, including the owner and most of these SMEs (40\%) have been in business for a period of 1-5 years.

Table 1: Descriptive statistics for ethical practices of SMEs

\begin{tabular}{lll}
\hline Item & Mean & Standard deviation \\
\hline The owners of this firm abide by the law. & 2.33 & 1.21 \\
We meet our tax obligations every financial year end & 1.87 & 0.66 \\
The contractual obligations in my organisation are always honoured. & 2.56 & 0.77 \\
We have clearly written policies to deal with our stakeholders. & 1.44 & 0.76 \\
Our business pays its suppliers on-time & 2.35 & 0.81 \\
All our employees are obligated to give customers accurate information. & 3.11 & 0.82 \\
We have clear policies to deal with customer complaints and & 2.86 & 0.85 \\
suggestions & & \\
Our policies protect employees from any form of discrimination. & 3.33 & 0.71 \\
Our employee evaluation process is pivoted on fairness. & 2.87 & 0.76 \\
We sometimes manipulate performance indicators & 4.21 & 0.77 \\
We create jobs for the local communities & 3.12 & 0.67 \\
Our business provides staff with training & 2.22 & 0.88 \\
There is friendship and interpersonal trust among employees. & 3.10 & 1.23 \\
Our stuff feels that they are fully supported by management in any & 2.66 & 0.87 \\
\hline
\end{tabular}


charitable work endeavours.

$\begin{array}{lll}\text { Our business treats its employees with dignity and respect. } & 3.25 & 0.96\end{array}$

Cronbach's alpha

0.80

Descriptive statistics for ethical practices of SMEs: Table 1 shows descriptive statistics for ethical practices of SMEs. As indicated, the mean scores on the question items are low. This shows that SMEs engage in unethical practices. In addition, the results indicate that SMEs have no formal policies in place to shape their ethical behaviour. The findings are consistent with similar studies (Arruda, 2010; Spence \& Perrini, 2010). It is further reported that SMEs cut a lot of corners to just make profits or close a deal that in most cases ethics are foregone (Arruda, 2010; Vivier, 2013). Unethical behaviors among SMEs include fraudulent activities, bribes, window-dressing financial statements, failing to meet commitments with suppliers and tax evasion among others. According to Harron, Ismail and Oda (2015), SMEs should embrace ethical values such as fairness, honesty, openness and integrity.

\section{Table 2: Factor analysis for ethical practices of SMEs}

\begin{tabular}{|c|c|c|c|c|}
\hline Item & Factor 1 & Factor 2 & Factor 3 & Factor 4 \\
\hline $\begin{array}{l}\text { Our policies protect employees from any form } \\
\text { of discrimination. }\end{array}$ & 0.81 & & & \\
\hline $\begin{array}{l}\text { Our employee evaluation process is pivoted on } \\
\text { fairness. }\end{array}$ & 0.77 & & & \\
\hline Our business provides staff with training & 0.74 & & & \\
\hline $\begin{array}{l}\text { Our stuff feels that they are fully supported by } \\
\text { management in any charitable work } \\
\text { endeavours. }\end{array}$ & 0.67 & & & \\
\hline $\begin{array}{l}\text { Our business treats its employees with dignity } \\
\text { and respect. }\end{array}$ & & & & \\
\hline Our business pays its suppliers on-time & & 0.79 & & \\
\hline $\begin{array}{l}\text { We sometimes manipulate performance } \\
\text { indicators }\end{array}$ & & 0.76 & & \\
\hline The owners of this firm abide by the law. & & & 0.77 & \\
\hline $\begin{array}{l}\text { We meet our tax obligations every financial } \\
\text { year end }\end{array}$ & & & 0.68 & \\
\hline $\begin{array}{l}\text { The contractual obligations in my organisation } \\
\text { are always honoured. }\end{array}$ & & & 0.62 & \\
\hline $\begin{array}{l}\text { We have clearly written policies to deal with } \\
\text { our stakeholders. }\end{array}$ & & & 0.60 & \\
\hline $\begin{array}{l}\text { All our employees are obligated to give } \\
\text { customers accurate information. }\end{array}$ & & & & 0.75 \\
\hline $\begin{array}{l}\text { We have clear policies to deal with customer } \\
\text { complaints and suggestions }\end{array}$ & & & & 0.69 \\
\hline Eigen value & 3.41 & 2.34 & 2.11 & 1.77 \\
\hline Percentage of variance explained (75.46\%). & 25.01 & 21.21 & 18.11 & 11. 13 \\
\hline Cronbach's alpha & 0.81 & 0.79 & 0.80 & 0.83 \\
\hline
\end{tabular}

Source: Principal components factor analysis with varimax rotation. Kaiser-Meyer-Olkin (KMO) test of sampling adequacy $=0.74$; Barlett Test of Sphericity $(B T S)=443.566, p=0.000$

Factor analysis for ethical practices of SMEs: Table 2 shows factor analysis results. As shown above, four factors with Eigen values greater than one were identified. These are factor 1 which comprises of ethical practices related to employees, factor 2 consisted of ethical practices related to suppliers, factor 3 consisted of ethical practices related to legal requirements and factor 4 comprises of ethical practices related to customers. Factors related to shareholders and the community were dropped due to low factor loadings. 
Table 3: Descriptive statistics for SMEs performance

\begin{tabular}{lll}
\hline Item & Mean & Stand deviation \\
\hline Sales growth & 4.23 & 1.33 \\
Market share growth & 3.12 & 0.79 \\
Profitability & 3.45 & 1.03 \\
Return on assets & 4.15 & 0.81 \\
Employment growth & 2.26 & 0.71 \\
Customer satisfaction & 2.10 & 1.22 \\
Customer satisfaction relative to competitors & 1.11 & 0.69 \\
Employee satisfaction & 1.44 & 0.91 \\
Overall performance & 3.39 & 0.82 \\
Cronbach's alpha & 0.79 & \\
\hline
\end{tabular}

Descriptive statistics for SMEs performance: In this study performance was measured in terms of market share growth, sales, profitability, return on assets, employment growth, customer satisfaction and employee satisfaction. A 5 point Likert scale ranging from excellent (1), good (2), not bad (3), not good (4) and no idea (5) was used. Table 3 shows descriptive statistics for SMEs performance. The findings show that SMEs display a weak performance. The findings indicate that SMEs are doing well in terms of customer satisfaction and employee satisfaction compared to other measures of performance. However, for the past 3 years the respondents reported that their overall performance was not good. The findings are consistent with similar studies (Atkinson, 2013; FinMark Trust, 2015; SME Growth Index, 2015) which stress that SMEs in South Africa are not performing optimally.

Test for difference in ethical practices: The second objective of the study was to examine the effect of owners' demographic characteristics such as gender and level of education on the ethical practices of SMEs. Four Factors were identified from factor analysis. These include factors related to: employees, suppliers, legal requirements and customers. Items relating to shareholders and the community were dropped due to low factor loadings.

Table 4: Gender differences on ethical practices

\begin{tabular}{lllll}
\hline Factor & Female & Male & t- statistic & Sig level \\
\hline Ethical practices relating to employees & 2.84 & 2.71 & 1.66 & 0.02 \\
Ethical practices relating to suppliers & 3,28 & 3,23 & 1.43 & 0.01 \\
Ethical practices relating to legal requirements & 2.77 & 2.73 & 1.69 & 0.03 \\
Ethical practices relating to customers & 2.98 & 2.29 & 1.51 & 0.00 \\
\hline
\end{tabular}

Sig 0.05

T test for gender differences on ethical practices: It is important to interrogate gender differences on how males and females treat ethical issues in their businesses. Table 3 presents findings on gender differences on ethical practices of SMEs. Importantly, the results indicate that there are gender differences on the ethical practices of SMEs. As indicated by the T test results, females tend to be more ethically sensitive than their male counterparts. Similarly, studies such as Hazlina and Seet (2010) as well as Castejón and López (2016) agree with the above findings. The findings lead to the decision to reject $\left(\mathbf{H}_{\mathbf{0}}\right)$ and accept $\left(\mathbf{H}_{\mathbf{1}}\right)$ which states that there is a significant relationship between gender and ethical practices of SMEs. It can be deduced that gender is an important determinant of ethical behaviour among SMEs.

Table 5: Level of education difference on ethical practices

\begin{tabular}{lllll}
\hline Factor & Matric \& below & Tertiary & t- statistic & Sig level \\
\hline Ethical practices relating to employees & 2.73 & 2.76 & 1.67 & 0.00 \\
Ethical practices relating to suppliers & 2,76 & 3,21 & 1.36 & 0.02 \\
Ethical practices relating to legal requirements & 2.70 & 2.75 & 1.55 & 0.01 \\
Ethical practices relating to customers & 2.96 & 2.33 & 1.58 & 0.43 \\
\hline
\end{tabular}
Sig 0.05 
T test for level of education difference: Table 4 presents the results about the level of education difference on ethical practices of SMEs. It can be deduced that there are education differences on the ethical practices of SMEs. Respondents with tertiary qualifications tend to be ethical than those with matric and below qualifications. The results are in agreement with similar studies (Herrera et al., 2014; Dutta \& Banerjee, 2011) which report that people with tertiary qualifications tend to take ethical issues more serious than their counterparts with matric and below. Logically one could conclude that attaining a certain tertiary level qualification enables one to understand legal regulations and policies well than those without since some of the material and content is included in the tertiary curriculum. The findings lead to the decision to reject $\left(\mathbf{H}_{\mathbf{0}}\right)$ and accept $\left(\mathbf{H}_{2}\right)$ which states that there is a significant relationship between education and the ethical practices of SMEs. It therefore means that education predicts ethical behaviour.

Table 6: Regression analysis results

\begin{tabular}{llll}
\hline Independent variables & Beta & T & Sig \\
\hline Ethical practices & 0.187 & 50.721 & .000 \\
\hline
\end{tabular}

Source: Data Analysis. Dependent variable: performance. Sig.>0.05

Relationship between ethical practices and performance: Table 5 display regression analysis results. The regression analysis results between ethical practices and performance are $(B=0.187, \operatorname{sig}=0.000)$. The results support the alternative hypothesis $\left(\mathbf{H}_{3}\right)$ that there is a significant relationship between ethical practices and performance of SMEs. Based on the confidence interval of $95 \%$ and Sig. $>0.05$ this led to the decision to reject the null hypothesis $\left(\mathbf{H}_{\mathbf{0}}\right)$ and accept the alternative hypothesis $\left(\mathbf{H}_{3}\right)$. The results are in agreement with similar studies (Hilman \& Gorondutse, 2013). This suggests that ethical behaviour has a bearing on the performance of SMEs.

\section{Conclusion}

SMEs have become beacons of hope towards improving economic growth and development of many countries globally. SMEs have played a key role in regions like the European Union, Asia and the United States with booming economies. It is without doubt that SMEs act as agents of change and engines for economic growth and development. However, it was discovered that a significant number of SMEs continue to suffer premature death. It has been noted that SMEs are involved in unethical behaviours such as tax aversion, failing to meet quality standards, lack of policies to protect employees and customers, fraudulent activities and selling of illegal substances among others. The authors of this study believe that unethical behaviour poses a threat to the sustainability of SMEs. Ethical conduct has become an important issue that SMEs should take serious lest they suffer negative consequences such as negative brand image, lawsuits, and lack of trust among different stakeholders in their networks. The $\mathrm{T}$ test results showed gender and education differences on the ethical practices of SMEs. This shows that both gender and education are crucial determinants of ethical behaviour among SMEs. The regression results confirmed that there is a significant relationship between ethical practices and performance of SMEs. Based on the confidence interval of $95 \%$ and Sig. $>0.05$ this led to the decision to reject the null hypothesis $\left(\mathbf{H}_{\mathbf{0}}\right)$ and accept the alternative hypothesis $\left(\mathbf{H}_{3}\right)$.

Recommendations: The government should relax rules and regulations governing small businesses. The authors of this paper argue that a significant number of SMEs end up involved in unethical practices in order to survive as there is little or no government assistance at their disposal. Hence, the government should relax the legal environment, by giving new start-ups tax holidays so that they can grow into future large businesses. Furthermore, it was discovered that education improves the ethical sensitivity of SME owners. Hence, the government should roll out skills development to educate SME owners on how to handle ethical issues in their businesses. On that note, The South African Revenue Service (SARS) should rule out a number of community outreach programs aimed at educating SMEs owners on the different tax obligations they have to meet and the procedures they have to follow. On our study, some respondents expressed that they were not paying tax because they were not knowledgeable about the procedures to be followed. Also the ministry of small businesses together with other government departments such as Small Enterprise Development Agency (SEDA) should device a consortium of programmes to educate SMEs about the importance of business ethics. 
In addition, SME owners are encouraged to familiarise themselves with different policies concerning, shareholders, suppliers, employees, customers and the community. This entails putting different policies in place to deal with different ethical issues such as employee enrichment, customer complaints, and a detailed corporate social responsibility stance. SME owner/managers are also encouraged to enrol for a certificate in business ethics as offered by a number of institutions in South Africa. This can take them a long way in understanding ethical dynamics in their businesses. Given that there are gender differences on the ethical behaviours exhibited by males and females, SMEs' management should take advantage of that to bring diversity in their organisations. Women tend to be philanthropic, respect relationships while men pursue the economic approach, ignoring ethics at times to maximize profits. Hence, merging these two approaches can result in organisations which are profitable while at the same time ethically sensitive. Overall, the government has a critical role to play in instilling a national culture which is ethically sensitive. This can be enforced by introducing punitive laws to individuals and companies which display unethical behaviour. Teams should be set and deployed to inspect ethical standards and policies in different companies. This should be implemented as a holistic approach, starting at national level until the community level. The authors of this study believe that this is one of the best approaches to end unethical behaviour among individuals and SMEs in South Africa.

\section{References}

African Development Bank. (2007). Annual Report. Online at http://www.afdb.org >Home > Knowledge > Publications > Annual Report. Accessed on 10 August 2015.

Agbenyegah, A. T. (2013). Challenges facing rural entrepreneurship in selected areas in South Africa (Doctoral dissertation, North-West University).

Ahmad, N. H., Amran, A. \& Halim, H. A. (2012). Ethical and Socially Responsible Practices among SME OwnerManagers: Proposing a Multi-Ethnic Assessment. Journal of Southeast Asian Research, 2, 1-9.

Arruda, M. C. (2010). Latin America: Ethics and corporate social responsibility in Latin American small and medium sized enterprises: Challenging development (pp. 65-84). In Spence, L. J. and PainterMorland, M. (Eds.). Ethics in small and medium sized enterprises: A global commentary. New York: Springer.

Atkinson, D. (2013). Review of The Efficiency and Effectiveness of Past and ongoing SME Development Initiatives in the Free State Province. Online at http://www.ilo.org/0316F229-D231. Accessed on 27 July 2015].

Brammer, S., Millington, A. \& Rayton, B. (2007). The Contribution of Corporate Social Responsibility to Organisational Commitment. International Journal of Human Resource Management, 18(10), 17011719.

Castejón, P. J. M. \& López, B. A. (2016). Corporate social responsibility in family SMEs: A comparative study. European Journal of Family Business, 6(1), 21-31.

Chinchilla A. M. N. \& Jiménez, E. (2013). Responsabilidadfamiliarcorporativa. Harvard Deusto Business Review, 228, 48-61.

D'imperio, R. (2012). Growing the Global Economy through SMEs. Edinburgh Group. Online at http://www.cpaireland.ie/UserFiles/File/Business\%20Development/Publications/Edinburgh\%20G roup\%20Research\%20Project.pdf. Accessed on 10 August 2015.

Dada, M. R. (2014). Commercial Banks' Credit and SMEs Development in Nigeria: An Empirical Review. International Journal of Research, 1(8), 305-319.

Dawson, L. M. (2013). Women and Men, Morality and Ethics. Online at http://homepages.se.edu/cvonbergen/files/2013/01/Women-and-Men-Morality-and-Ethics.pdf. Accessed on 04 February 2017.

Donker, H., Poff, D. \& Zahir, S. (2008). Corporate Values, Codes of Ethics, And Firm Performance: A Look at the Canadian Context. Journal of Business Ethics, 82(3), 527-537.

Dutta, S. \& Banerjee, S. (2011). Ethical practices towards employees in small enterprises: A quantitative index. International Journal of Business Management \& Economic Research, 2(3), 205-221.

Elms, H., Berman, S. \& Wicks, A. C. (2002). Ethics and incentives: An evaluation and development of stakeholder theory in the health care industry. Business Ethics Quarterly, 12(4), 413-432. 
Fatoki, O. (2012). The Impact of Ethics on the Availability of Trade Credit to New Small and Medium Sized Enterprises (SMEs) in South Africa. Journal of Social Science, 30(1), 21-29.

FinMark Trust. (2015). Financial Access and SME Size in South Africa. Online at http://www.finmark.org.za/0e91471136eb493c9771c15a0d591dee/finaldownload/downloadida5f 7b10bf38c64bc80af7dbaacf46010/0e91471136eb493c9771c15a0d591dee/wpcontent/uploads/20 16/01/rep_financial-access-and-sme-size-in-sa_dec2015-1.pdf. Accessed on 17 March 2016.

Firoozmand, S., Haxel, P., Jung, E. \& Suominen, K. (2015). State of SME Finance in theUnitedStatesin2015.0nlineathttp://www.tradeupfund.com/.../state_of_sme_finance_in_the_unite d_states_2.Accessed on 7 July 2015.

Freeman, R. E. (1984). Strategic Management: A Stakeholder Approach. Boston: Pitman.

Freeman, R. E., Wicks, A. C. \& Parmar, B. (2004). Stakeholder theory and "the corporate objective revisited". Organization science, 15(3), 364-369.

Government Gazette of the Republic of South Africa. (2003). National Small Business Amendment Act. Online at http:/ /www.info.gov.za/gazette/acts/2003/a26-03.pdf. Accessed on 10 August 2015.

Harron, H., Ismail, I. \& Oda, S. (2015). Ethics, corporate social responsibility and the use of advisory services provided by SMEs: Lessons learnt from Japan. Asian Academy of Management Journal, 20(1), $71-100$.

Hazlina, N. \& Seet, P. S. (2010). Gender variations in ethical and socially responsible considerations among SME entrepreneurs in Malaysia. International Journal of Business and Society, 11(1), 77-88.

Hellriegel, D., Jackson, S. E., Slocum, J., Staude, G., Amos, T., Klopper, H. P., Louw, L. \& Oosthuizen, T. (2008). Management. 2nd Edition South African. Oxford: Oxford University Press.

Herrera-Madruẽno, J., Larrán-Jorge, M., Lechuga-Sancho, M. P. \& Martínez-Martínez, D. (2014). Motivacioneshacia la Responsabili-dad Social en las PymesFamiliares. Revista de Empresa Familiar, $4(1), 21-44$.

Hilman, H. \& Gorondutse, A. H. (2013). Relationship between Perceived Ethics and Trust of Business Social Responsibility (BSR) on Performance of SMEs in Nigeria. Middle-East Journal of Scientific Research, 15(1), 36-45.

Ilegbinosa, I. A. \& Jumbo, E. (2015). Small and Medium Scale Enterprises and Economic Growth in Nigeria: 1975-2012. Journal of Business and Management, 10(3), 203-216.

International Finance Corporation Report. (2013). Assessing Private Sector ContributionstoJobCreationandPovertyReduction.Onlineathttp://www.ifc.org/wps/wcm/connect/d 3b612004e3468c783d5ab7a9dd66. Accessed on 11 July 2015.

Kamyabi, Y., Barzegar, G. \& Kohestani, A. (2013). The Impact of Corporate Social Responsibility on Iranian SME Financial Performance. Journal of Social Issues and Humanities, 1(5), 2345-2633.

Key, S. (1999). Organizational ethical culture: real or imagined? Journal of Business Ethics, 20(3), 217-225.

Key, S., Bewley, L. \& Vault, S. (2004). Stakeholder theory around the world: A twenty-year retrospective. In Proceedings of Academy of International Business, Southeast USA, Annual Meeting, Knoxville, TN.

Kim, T. K. (2015). T test as a parametric statistic. Korean journal of anesthesiology, 68(6), 540-546.

Kongolo, M. (2010). Job Creation versus Job Shedding and the Role of SMEs in Economic Development. African Journal of Business Management, 4(11), 2288-2295.

Larrán-Jorge, M., AndradesPẽna, F. J. \& Muriel de los Reyes, M. J. (2014). La responsabilidad social corporativaen las titula-ciones de empresa y marketing ofertadaspor las universidadesespa nolas. ESIC Market Economics and Business Journal, 45(1), 121-146.

Lather, A. S. (2009). Measuring The Ethical Quotient of Corporations: The Case of Small and Medium Enterprises in India. Forum on Public policy, Spring. Online at http://forumonpublicpolicy.com/spring09papers/archivespr09/lather.pdf. Accessed on 13 April 2015.

Manaf, A. H. A. \& Latif, L. A. (2014). Transformational Leadership and Job Performance of SMEs Technical Personnel: The Adaptability Cultural Approach as Mediator. Mediterranean Journal of Social Sciences, $5(20), 648-655$.

Peprah, J. A., Mensah, A. O. \& Akosah, N. B. (2016). Small and Medium Sized Enterprises (SMEs) Accessibility to Public Procurement: SMEs Entity Perspective in Ghana. European Journal of Business and Social Sciences, 4(11), 25-40. 
Pérez H. D. C. (2010). Perfil del profesionaluniversitariofuturogerentePyme, fortalezasustentable para el desarrolloendógeno. CICAG: Revista del Centro de Investigación de Cien-ciasAdministrativas y Gerenciales, 7(2), 1-13.

Schlierer, H., Werner, A., Signori, S., Garriga, E., von Weltzein Hoivik, H., Van Rossem, A. \& Fassin, Y. (2012). How do European SME owner-managers make sense of 'stakeholder management? Insights from a cross-national study. Journal of Business Ethics, 109, 39-51.

Sekaran, U. \& Bougie, R. (2010). Research Methods for Business: A Skill Building Approach (5th edition). New Jersey: John Wiley and Sons.

SME Growth Index, (2015). SME sustainability and growth should be an obsession for job creation in South Africa. Online at http://smegrowthindex.co.za/. Accessed on 04 May 2016.

Smit, P. J., Cronje, G. J., Brevis, T. \& Vrba, M. J. (2007). Management Principle: A Contemporary Edition for Africa. Cape Town: Juta and Co Ltd.

Spence, L. \& Painter-Morland, M. (2010). Ethics in small and medium sized enterprises: A global commentary. New York: Springer.

Spence, L. \& Perrini, F. (2010). Europe: Practice and politics: Ethics and social responsibility in SMEs in the European Union. In Spence, L. J. and Painter-Morland, M. (Eds.). Ethics in small and medium sized enterprises: A global commentary. (pp. 35-54). New York: Springer.

Tsele, L. (2015). Female entrepreneurship: Is South Africa winning the gender inequality struggle? Available at http://www.smesouthafrica.co.za/15922/Female-entrepreneurship-Is-South-Africa-winning-thegender-inequality-struggle/. Accessed on 23 April 2017.

Vivier, E. (2013). A tough line to work through: Ethical ambiguities in a South African SME. African Journal of Business Ethics, 7(2), 68-78.

Viviers, S. \& Venter, D. (2008). Fraud: An SMME perspective. Southern African Journal of Entrepreneurship and Small Business Management, 1, 51-65. 